\title{
Biomarkers in Breast Cancer - An Update
}

\author{
Biomarker beim Mammakarzinom - ein Update
}

Authors

Affiliations
M. Schmidt ${ }^{1}$, P. A. Fasching ${ }^{2}$, M. W. Beckmann² ${ }^{2}$ H. Kölbl ${ }^{1}$

${ }^{1}$ Klinik für Geburtshilfe und Frauenkrankheiten, Universitätsmedizin Mainz, Mainz

2 Frauenklinik, Universitätsklinikum Erlangen, Erlangen
Key words

- biomarker

- Her2/neu (human epidermal growth factor receptor)

- breast cancer

Schlüsselwörter

- Biomarker

- Her-2/neu

- Mammakarzinom received 8.8.2012

accepted $\quad 8.8 .2012$

Bibliography

Dol http://dx.doi.org/ 10.1055/s-0032-1315340

Geburtsh Frauenheilk 2012; 72:

819-832 @ Georg Thieme

Verlag KG Stuttgart · New York .

ISSN 0016-5751

\section{Correspondence}

\section{Dr. Marcus Schmidt}

Universitätsmedizin Mainz

Klinik für Geburtshilfe und

Frauenkrankheiten

Langenbeckstraße 1

55101 Mainz

marcus.schmidt@

unimedizin-mainz.de

\section{Abstract}

\section{$\nabla$}

The therapy of choice for breast cancer patients requiring adjuvant chemo- or radiotherapy is increasingly guided by the principle of weighing the individual effectiveness of the therapy against the associated side effects. This has only been made possible by the discovery and validation of modern biomarkers. In the last decades and in the last few years some biomarkers have been integrated in clinical practice and a number have been included in modern study concepts. The importance of biomarkers lies not merely in their prognostic value indicating the future course of disease but also in their use to predict patient response to therapy. Due to the many subgroups, mathematical models and computer-assisted analysis are increasingly being used to assess the prognostic information obtained from established clinical and histopathological factors. In addition to describing some recent computer programmes this overview will focus on established molecular markers which have already been extensively validated in clinical practice and on new molecular markers identified by genomewide studies.

\section{Introduction \\ $\nabla$}

In the last few decades breast cancer mortality in western industrialised countries has decreased [1]. The reasons for this decreased mortality include improvements in early diagnosis and the postoperative use of effective adjuvant therapies [2-4].

Two important questions are used to shape the decision regarding systemic therapy: who should receive therapy, and which therapy should be ad-

\section{Zusammenfassung \\ $\nabla$}

Die Therapiewahl für die Mammakarzinompatientin in der adjuvanten Situation folgt immer mehr dem Prinzip, die individuelle Therapieeffektivität und die Nebenwirkungen gegeneinander abzuwägen. Die Entdeckung und Validierung moderner Biomarker ermöglicht erst dieses Vorgehen. In den letzten Jahrzehnten und insbesondere in den letzten Jahren konnten einige Biomarker in die klinische Praxis und in moderne Studienkonzepte integriert werden. Nicht nur der Vorhersage der Prognose kommt hierbei eine besondere Bedeutung zu, sondern auch der Vorhersage des Therapieansprechens durch Prädiktivfaktoren. Die Nutzung der prognostischen Information aus etablierten, klinischen und histopathologischen Faktoren erfolgt aufgrund der Vielzahl von Untergruppen mehr und mehr in Form von mathematischen Modellen und computergestützter Auswertung. Neben der Darstellung aktueller Programme soll in dieser Übersichtsarbeit des Weiteren der Fokus auf etablierten, molekularen Markern, die bereits eine umfassende klinische Validierung vorweisen können, und neuen molekularen Markern liegen, die durch genomweite Ansätze identifiziert wurden.

\section{Einleitung \\ $\nabla$}

In den letzten Dekaden hat die Mortalität am Mammakarzinom in den westlichen Industrieländern abgenommen [1]. Gründe für diese Abnahme liegen zum einen in der verbesserten Früherkennung und zum anderen im postoperativen Einsatz von effektiven adjuvanten Therapien [2-4].

Zwei wesentliche Fragen beeinflussen die Entscheidung über eine systemische Therapie: Zum einen, wer soll behandelt werden und zum anderen, wie 

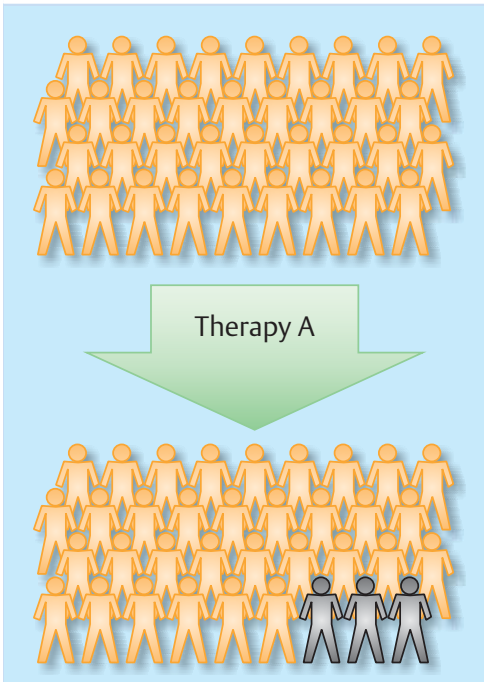

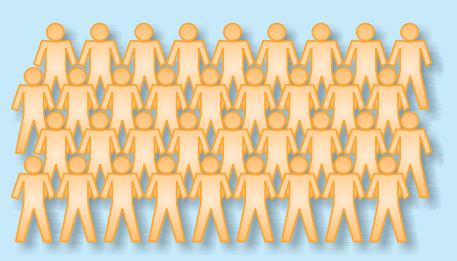

Fig. 1 Standard empirical comparison using two comparable groups of patients. It appears that fewer patients had recurrence after therapy A (black figures). The conclusion of such a comparative study is that therapy A must be better. ministered? Biomarkers can help answer these questions for patients with breast cancer.

Prognostic factors offer a prognosis for breast cancer patients but do not take account of adjuvant pharmacotherapies or help decide which patients should receive treatment. Predictive factors are used to rate the prognosis while taking account of specific adjuvant therapies. They provide information on non-response or sensitivity to specific therapies and help decide which therapy is suitable for the individual patient.

Given these presuppositions, the prognostic impact of markers can only be evaluated within patient collectives who do not undergo adjuvant systemic therapy. By now, however, almost all patients receive adjuvant therapy so it is important to keep in mind that the observed impact on survival represents a combination of prognostic and predictive effects.

\section{Principles of Planning Adjuvant Therapy \\ $\nabla$}

Up to now, most of the knowledge regarding the choice of therapy has been based on prognostic factors. Therapies for women with a poor prognosis were generally compared using large, prospective randomised studies. If one of the therapies turned out to offer better outcomes, this therapy was subsequently selected as the therapy of choice for this group of patients ( $\mathbf{F i g . 1}$ ). This procedure has the critical disadvantage that the statement regarding the benefits of the adjuvant therapy is made with regard to a group of patients. Depending on the circumstances, the statement may be completely irrelevant for an individual patient: in the event that the patient does not suffer recurrence this can be explained either by postulating that the therapy was effective and prevented recurrence or that the patient would not have had recurrence even without adjuvant therapy. In the latter case, the woman would have unnecessarily endured the side effects of the therapy ( Fig. 2). For this reason it is important to identify the group of women prior to adjuvant therapy, in whom the therapy will be most effective and who will have the lowest rate of side effects ( Fig. 3). The hope is that such a differentiation will become possible through the increased use of well validated biomarkers. soll behandelt werden. Biomarker können bei der Beantwortung dieser Fragen beim Mammakarzinom helfen.

Prognostische Faktoren schätzen die Prognose des Mammakarzinoms ohne spezielle Berücksichtigung einer adjuvanten medikamentösen Therapie ab und helfen zu beurteilen, welche Patientin behandelt werden soll. Prädiktive Faktoren dienen zum Einschätzen der Prognose unter Berücksichtigung einer speziellen adjuvanten Therapie. Sie sind daher mit der Resistenz oder Sensitivität für eine spezielle Therapie verknüpft und unterstützen bei der Entscheidung, mit welcher Therapie die Patientin behandelt werden soll.

Unter diesen Voraussetzungen kann der rein prognostische Effekt eines Markers nur in einem Kollektiv von Patientinnen evaluiert werden, die nicht mit einer adjuvanten Systemtherapie behandelt worden sind. Mittlerweile werden allerdings alle Patientinnen adjuvant behandelt, sodass man hier berücksichtigen muss, dass der beobachtete Effekt auf das Überleben eine Mischung aus prognostischen und prädiktiven Effekten darstellt.

\section{Prinzipien der Therapieplanung}

Bisher wurde das meiste Wissen über die Therapiewahl anhand von Prognosefaktoren getroffen. In der Gruppe der Frauen mit der entsprechend schlechten Prognose wurden meistens Therapien in großen, prospektiv randomisierten Studien miteinander verglichen. Hatte sich eine der Therapien als besser herausgestellt, so konnte man sagen, dass für diese Gruppe der Patientinnen in Zukunft die entsprechend bessere Therapie gewählt werden sollte ( $\bullet$ Abb. 1). Dieses Vorgehen hat aber dahingehend entscheidende Nachteile, dass nur für die Gruppe der Frauen diese Aussage gemacht werden konnte. Für die individuelle Patientin hat dies unter Umständen keine Bedeutung, denn für den Fall, dass eine Patientin keinen Rückfall erlitten hat, kann dies entweder dadurch erklärt werden, dass die Therapie gewirkt hat und die Patientin deswegen keinen Rückfall erlitten hatte, oder dass sie auch ohne Therapie keinen Rückfall erlitten hätte. Für den letzten Fall hätte die Frau unnötig die Nebenwirkungen der Therapie ertragen müssen ( Abb. 2). Deswegen muss gefordert werden, dass man vor der Therapie die Gruppe der Frauen identifizieren kann, bei der die Therapieeffektivität am höchsten und die Nebenwirkungsrate am geringsten ist ( Abb. 3). Die Hoffnung ist, dass diese Differenzierung durch den zunehmenden Gebrauch von gut validierten Biomarkern möglich wird. 

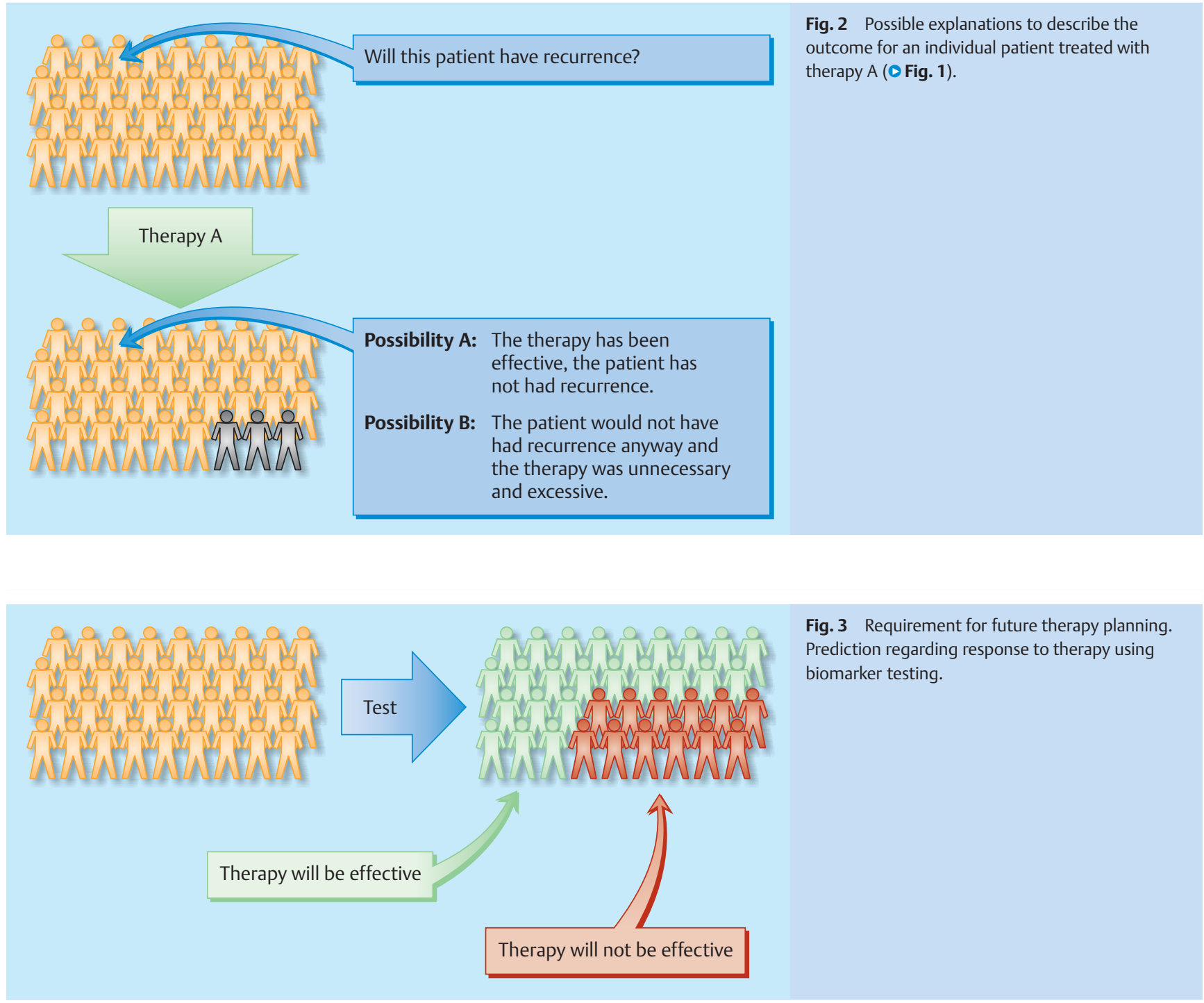

\section{Planning Adjuvant Therapy in Practice \\ $\nabla$}

The current dominant paradigm in adjuvant targeted therapy of breast cancer is "first - select the target" $[5,6]$. Predictive factors such as oestrogen receptor (ER) and human epidermal growth factor receptor-2 (HER2) are of primary importance in this context. However, interest has increasingly focused on improving risk assessment based on prognostic factors. The current metaanalysis in the Early Breast Cancer Trialists' Collaborative Group (EBCTCG) has shown that anthracycline- and taxane-based chemotherapy decreases breast cancer-associated 10 -year mortality by about one third. However, the authors expressly state that this depends to a critical extent on the baseline risk of the patient if she does not undergo chemotherapy. Patients with a low absolute risk will only have a low absolute benefit from adjuvant chemotherapy [7]. In the recent St. Gallen Consensus [8,9] the therapy recommendations were based for the first time on so-called intrinsic subtypes in breast cancer. The Consensus differentiated between luminal A, luminal B, HER2-positive and triple negative (no expression of ER, progesterone receptor [PR] and HER2) types, and the therapy recommendations were made accordingly (O Table 1). Adjuvant chemotherapy is indicated for differentiated triple negative and for HER2-positive breast cancers. How-

\section{Therapieplanung in der Praxis}

Nachdem in der adjuvanten Therapie des Mammakarzinoms das Paradigma der zielgerichteten Therapie, „First - select the target“, dominiert $[5,6]$, und v.a. prädiktive Faktoren wie der Östrogenrezeptor (ER) und der Human Epidermal Growth Factor Receptor-2 (HER2) von Bedeutung für die adjuvante Therapie sind, rückt eine verbesserte Risikoeinschätzung mit prognostischen Faktoren mehr und mehr in den Fokus des Interesses. In der aktuellen Metaanalyse der Early Breast Cancer Trialists' Collaborative Group (EBCTCG) konnte gezeigt werden, dass eine anthrazyklin- und taxanhaltige Chemotherapie die brustkrebsassoziierte 10-Jahres-Mortalität um etwa ein Drittel senkt. Die Autoren erwähnten allerdings explizit, dass dies allerdings entscheidend vom Ausgangsrisiko der Patientin ohne Chemotherapie abhängt. Patientinnen mit einem geringen absoluten Risiko haben daher nur einen geringen absoluten Nutzen durch eine adjuvante Chemotherapie [7]. In dem aktuellen St.-Gallen-Konsensus [8,9] erfolgt die Therapieempfehlung erstmals analog der sog. intrinsischen Subtypen beim Mammakarzinom. Hier wird zwischen luminal A, luminal B, HER2-positiv und triple-negativ (keine Expression von ER, Progesteronrezeptor [PR] und HER2) unterschieden und die Therapie dementsprechend festgelegt ( $\boldsymbol{O}$ Tab. 1). Während bei den triple-negativ differenzierten und bei den HER2-positiven Mamma- 
Table 1 Therapy recommendations of the recent St. Gallen Consensus [8]. (ET: endocrine therapy; CT: chemotherapy; Anti-HER2: anti-HER2 therapy).

\begin{tabular}{ll} 
Subtype & Therapy \\
Luminal A & ET \\
\hline Luminal B (HER2 negative) & ET \pm CT (“after risk assessment”) \\
\hline Luminal B (HER2 positive) & CT + Anti-HER2 + ET \\
\hline HER2 positive (non-luminal) & CT + Anti-HER2 \\
\hline Triple negative & CT \\
\hline
\end{tabular}

ever, individual risk assessment is necessary for hormone receptor-positive breast cancers, particularly as a definitive differentiation between luminal A and luminal B is often difficult in everyday clinical practice.

\section{Computer-assisted Assessment of Prognosis} $\nabla$

\section{Adjuvant!}

As many different prognostic and predictive factors are now being used to differentiate the many subtypes from one another and as factors may also interact with one another, several computer programmes have been developed in the last few years to create an individual, mathematical risk prediction for an individual patient based on the experience obtained from several thousand patients.

Adjuvant! is a frequently employed algorithm used for risk assessment. The internet-based algorithm includes established clinical and pathological prognostic factors such as tumour size, nodal status, oestrogen receptor status (ER), degree of histological differentiation and age. The use of these factors in clinical practice has been unambiguously recommended (++) by the Study Group for Gynaecological Oncology (AGO), [10]. Adjuvant! uses the parameters described above together with an assessment of co-morbidities to calculate the risk for recurrence-free survival and total survival after 10 years. It can additionally be used to calculate the potential benefit of different adjuvant endocrine therapies and chemotherapies. This allows the oncologist to provide better individual advice to patients and represents a further step on the way to an individualised treatment of breast cancer. AGO has recommended the use of Adjuvant! (recommendation: +).

Adjuvant! has now been validated in numerous studies. Olivotto et al. were able to demonstrate a reliable prognostic assessment in a cohort of 4083 breast cancer patients [11]. Another validation in 5380 patients in the Netherlands showed that Adjuvant! accurately predicted the 10 -year survival rate of the total collective [12]. However, the concordance index for breast cancer survival for individual patients was merely 0.71 . This shows that even with computer-assisted optimised risk models it is not possible to reliably predict the individual prognosis of an individual patient.

One advantage of Adjuvant! is that it also includes the patient's co-morbidities in addition to the above-mentioned established clinico-pathological prognostic factors in its computational model. A retrospective study using sensitivity analysis showed that prognosis of 10-year morbidity also depended on the individual patient's existing co-morbidities [13]. As expected, this effect was particularly pronounced in older patients. In each case these karzinomen eine adjuvante Chemotherapie indiziert ist, muss bei hormonrezeptorpositiven Mammakarzinomen eine Risikoabschätzung durchgeführt werden, zumal die Unterscheidung zwischen luminal A und luminal B in der täglichen Praxis oft nicht eindeutig getroffen werden kann.

\section{Computergestützte Prognoseabschätzung \\ $\nabla$}

Adjuvant!

Da die verschiedenen Prognose- und Prädiktivfaktoren mittlerweile viele Subgruppen voneinander differenzieren und auch miteinander interagieren können, sind in den letzten Jahren mehrere Computerprogramme entwickelt worden, die dabei helfen, eine individuelle, mathematische Risikoprädiktion für die einzelne Patientin auf der Basis der Erfahrungen von mehreren Tausend Patientinnen zu ermöglichen.

Ein häufig zur Risikoabschätzung verwendeter Algorithmus ist Adjuvant!. Die etablierten klinisch-pathologischen Prognosefaktoren wie Tumorgröße, Nodalstatus, Östrogenrezeptorstatus (ER), histologischer Differenzierungsgrad und Alter, deren Verwendung in der klinischen Routine von der Arbeitsgemeinschaft für Gynäkologische Onkologie (AGO) eindeutig mit ++ empfohlen wird, werden in diesem internetbasierten Algorithmus berücksichtigt [10]. Adjuvant! kalkuliert mit den oben angegebenen Parametern sowie einer Einschätzung der Komorbiditäten eine Risikoabschätzung für das rezidivfreie Überleben und das Gesamtüberleben nach 10 Jahren. Darüber hinaus bietet es die Möglichkeit, den potenziellen Nutzen unterschiedlicher adjuvanter endokriner Therapien und Chemotherapien zu berechnen. Dies gibt dem onkologisch tätigen Arzt die Möglichkeit, seine Patientinnen noch individueller zu beraten und ist ein weiterer Schritt hin zu einer personalisierten Behandlung von Brustkrebs. Die Verwendung von Adjuvant! wird von der AGO mit + empfohlen.

Adjuvant! wurde mittlerweile in zahlreichen Untersuchungen validiert. Olivotto et al. konnten in einer Kohorte von 4083 Mammakarzinompatientinnen eine verlässliche Prognoseabschätzung mit Adjuvant! nachweisen [11]. Eine weitere Validierung bei 5380 Patientinnen aus Holland zeigte, dass Adjuvant! das 10-Jahres-Überleben im Gesamtkollektiv akkurat voraussagte [12]. Bezogen auf individuelle Patientinnen betrug der Konkordanzindex allerdings lediglich 0,71 für das brustkrebsspezifische Überleben. Dies zeigt, dass auch mit rechnergestützt optimierten Risikomodellen die individuelle Prognose der einzelnen Patientin nicht verlässlich vorhergesagt werden kann.

Ein Vorteil von Adjuvant! ist, dass neben den oben erwähnten etablierten klinisch-pathologischen Prognosefaktoren auch die Komorbidität der Patientinnen in dem Berechnungsmodell berücksichtigt wird. In einer retrospektiven Analyse konnte mithilfe von Sensitivitätsuntersuchungen eindeutig gezeigt werden, dass die Vorhersage der 10-Jahres-Morbidität auch von den vorliegenden Komorbiditäten der jeweiligen Patientin abhängt [13]. Dieser Effekt war erwartungsgemäß besonders bei älteren Patientinnen ausgeprägt. In jedem Fall zeigen diese Resultate die große Bedeutung einer akkuraten Einschätzung der jeweils vorliegenden Komorbidität für die Prognoseabschätzung beim Mammakarzinom.

In einer weiteren retrospektiven Analyse wurde Adjuvant! mit der Risikoeinteilung nach St. Gallen 2007 und einem neu entwickelten Risikoscore, der prospektiv im Rahmen der Node-Negative-Breast-Cancer-3 (NNBC-3) Studie untersucht wurde, bei 410 nodal-negativen und adjuvant unbehandelten Patientinnen verglichen [14]. Nodal-negative Patientinnen werden im NNBC-3-Algorithmus als Hochrisiko 
results demonstrated the importance of the accurate assessment of existing co-morbidities in individual patients for prognosis. In another retrospective analysis, Adjuvant! was compared to risk classification based on St. Gallen 2007 and a newly developed risk score, which was prospectively investigated as part of the Node-Negative Breast Cancer-3 (NNBC-3) study, in 410 node-negative patients without adjuvant therapy [14]. Nodenegative patients were classified as high risk using the NNBC-3 algorithm if one of the following factors was present: 1) age $<35,2)$ G III, 3) HER2 positive, 4) vascular invasion, 5) progesterone receptor (PR) negative, 6) G II and tumour size $>2 \mathrm{~cm}$. All other patients were considered low risk. This algorithm can be used for simple risk classification using the clinico-pathological criteria which are available for all patients prior to the decision for therapy.

Use of this risk algorithm showed an independent association with survival using multivariate analysis and increased the percentage of the low-risk group to $37 \%$ of patients, compared to $17 \%$ with Adjuvant! and 18\% using the St. Gallen classification.

\section{PREDICT+}

PREDICT+ is another model which is largely based on integrated data from European patients (www.predict.nhs.uk) [15-17]. This model differs from Adjuvant! in that the calculation of prognosis is based on two mathematical models which separately calculate the prognosis for ER-positive and ER-negative patients. This was based on the idea that other prognostic factors may have quite different effects in the two patient collectives. A direct comparison showed that PREDICT+ and Adjuvant! arrived at similarly accurate results.

One way to increase the prognostic validity of such clinico-pathological risk classifications even further could be the inclusion of proliferation markers such as Ki-67. In a study of 1080 breast cancer patients, Jung et al. showed that Ki-67 was an independent prognostic factor for disease-free and total survival and provided additional information compared to both the St. Gallen risk classification and Adjuvant! [18].

\section{Ki-67}

Proliferation is a clear biomarker signal both for prognosis and for prediction regarding the effectiveness of therapy. Ki-67 is the most commonly used marker in clinical practice.

Numerous study groups have investigated Ki-67 in primary breast cancer. Viale et al. reported that Ki-67 is a good prognostic factor in breast cancer patients [19]. Other authors using published studies on Ki-67 expression in breast cancer patients concluded that increased expression of Ki-67 was associated with a worse prognosis and a better response to chemotherapy. However, the independent prognostic validity was only moderate and these authors did not consider that determination of Ki-67 had any value in clinical practice [20]. Despite these limitations, use of Ki-67 is explicitly recommended in the most recent St. Gallen Consensus to divide the large group of receptor-positive breast cancers into luminal A and luminal B [8]. Cheang et al. showed that immunohistochemical determination of ER, PR, HER2 and the proliferation marker Ki-67 can be used to differentiate between luminal A and luminal B and that this differentiation correlated significantly with prognosis [21]. The Study Group for Gynaecologic Oncology (AGO) proposed the use of Ki67 as a prognostic factor ( $+=$ recommended).

Possible reasons for the differences in the validity of Ki-67 reported in various studies could be that, compared to ER/PR [22] klassifiziert, wenn einer der folgenden Faktoren gegeben ist: 1) Alter $<35$, 2) G III, 3) HER2-positiv, 4) Gefäßinvasion, 5) Progesteronrezeptor-(PR-)negativ, 6) G II und Tumorgröße $>2 \mathrm{~cm}$. Alle anderen Patientinnen werden der Niedrigrisikogruppe zugeordnet. Dieser Algorithmus ermöglicht eine einfache Risikoeinteilung mit klinischpathologischen Kriterien, die bei allen Patientinnen vor der Therapieentscheidung vorliegen.

Die Verwendung dieses Risikoalgorithmus war multivariat unabhängig mit dem Überleben assoziiert und vergrößerte die Niedrigrisikogruppe auf $37 \%$, während diese Gruppe nach Adjuvant! 17\% und St. Gallen $18 \%$ der Patientinnen umfasste.

\section{PREDICT+}

Ein weiteres Modell, welches zu einem großen Teil auch Daten von europäischen Patientinnen integriert hat, ist PREDICT+ (www.predict. nhs.uk) [15-17]. Dieses Modell unterscheidet sich von Adjuvant! dadurch, dass die Berechnung der Prognose auf 2 mathematischen Modellen beruht, die die Prognose für ER-positive und ER-negative Patientinnen getrennt berechnet haben. Hintergrund ist, dass die anderen Prognosefaktoren sich für die beiden Patientinnenkollektive durchaus unterschiedlich verhalten können. Beim direkten Vergleich schienen PREDICT+ und Adjuvant! ähnlich genau zu sein.

Ein möglicher Weg, um die prognostische Aussagekraft solcher klinisch-pathologischer Risikoklassifikationen weiter zu steigern, kann die Berücksichtigung von Proliferationsmarkern wie Ki-67 sein. Jung et al. demonstrierten in 1080 Brustkrebspatientinnen, dass Ki-67 ein unabhängiger prognostischer Faktor für das erkrankungsfreie und das Gesamtüberleben ist und zusätzliche Informationen sowohl zur St.-Gallen-Risikoeinteilung als auch zu Adjuvant! liefert [18].

\section{Ki-67}

Die Proliferation ist ein deutliches Biomarkersignal, sowohl für die Prognose als auch die Prädiktion des Therapieansprechens. Ki-67 ist hierbei der Marker, der in der klinischen Praxis am weitesten verbreitet ist.

Zahlreiche Arbeitsgruppen haben Ki-67 beim primären Mammakarzinom untersucht. Viale et al. stellten fest, dass Ki-67 ein guter Prognosefaktor beim Mammakarzinom ist [19]. Andere wiederum konnten unter Berücksichtigung der zu Ki-67 beim Mammakarzinom publizierten Studien zwar schlussfolgern, dass eine erhöhte Expression von Ki-67 mit einer verschlechterten Prognose und einem verbesserten Ansprechen auf eine Chemotherapie assoziiert ist. Allerdings war die unabhängige prognostische Aussagekraft nur mäßig, sodass diese Autoren keinen Stellenwert für die Bestimmung von Ki-67 in der klinischen Routine sahen [20]. Trotz dieser Limitationen wird Ki-67 im aktuellen St.-Gallen-Konsensus explizit empfohlen, um die große Gruppe der rezeptorpositiven Mammakarzinome in luminal A und in luminal B zu gliedern [8]. Von Cheang et al. konnte gezeigt werden, dass durch immunhistochemisch bestimmten ER, PR, HER2 und dem Proliferationsmarker Ki-67 die Unterscheidung zwischen luminal A und luminal B möglich ist, und diese Einteilung signifikant mit der Prognose korrelierte [21]. Die Arbeitsgemeinschaft für Gynäkologische Onkologie (AGO) bewertet Ki-67 als Prognosefaktor mit + (empfehlenswert).

Mögliche Gründe für die Unterschiede in der Aussagekraft von Ki-67 zwischen einzelnen Studien können darin bestehen, dass Ki-67 im Vergleich zu ER/PR [22] und HER2 [23] derzeit noch nicht optimal bez. der präanalytischen Variablen, der Grenzwerte für die Positivität und die Interpretationskriterien standardisiert ist und daher die Reproduzierbarkeit oft nicht optimal ist. Um die Methodik der Ki-67Bestimmung zu harmonisieren und dadurch eine verbesserte Ver- 
and HER2 [23], Ki-67 has not yet been optimally standardised with regard to pre-analytical variables, positivity threshold and interpretation criteria, and therefore the reproducibility of results is often not optimal. An international study group has recently published its recommendations on standardising the methods of Ki-67 determination to improve the comparability of results [24]. In view of the fact that both Ki-67 and ER or HER2 test results can be incorrect, improved quality controls and quality assurance programmes are very important to allow the prognostic and predictive potential of these markers to be fully utilised.

\section{Development of Biomarkers in Breast Cancer $\nabla$}

In addition to the above-mentioned established clinico-pathological factors, numerous modern prognostic and predictive factors focussing on tumour biology have been investigated in the last few decades. Of these, only hormone receptor status and HER2 are widely accepted as offering a high level of evidence and are generally used in clinical practice. The REMARK (Reporting Recommendations of Tumor Marker Prognostic Studies) criteria were introduced to improve the quality of research on biomarkers. REMARK describes which information, e.g., study design, primary hypothesis, patient and tissue characteristics, method of detection and statistical method used for analysis, need to be disclosed when publishing a study on biomarkers [25]. Depending on the quality of the biomarker study, it is possible to allocate different levels of evidence to individual markers [26]. To achieve the highest level of evidence, a biomarker would need to be investigated prospectively in a prospective randomised study. In the meantime a modification of the evidence levels for biomarkers has been introduced which takes greater account of already existing and archived tissue [27]. A priori investigations in prospective randomised studies are still considered the gold standard. In view of the fact that such studies to evaluate tumour markers are both very expensive and difficult to organise, the use of more efficient "prospective-retrospective" approaches using archived material from prospective studies has been proposed. Such an approach could also achieve evidence level I if the results using archived material are then validated in a second comparable study [27].

The recommendations on the use of more recently developed biomarkers in breast cancer were updated by the American Society of Clinical Oncology (ASCO) [28]. In addition to ER and HER2, ASCO has recommended using additional biomarkers such as urokinase plasminogen activator (uPA)/plasminogen activator inhibitor-1 (PAI-1) and certain gene expression algorithms in clinical practice.

\section{Urokinase Plasminogen Activator| Plasminogen Activator Inhibitor-1 $\nabla$}

uPA and PAI- 1 are components of the plasminogen activating system and have been found in experiments to be linked to invasion, angiogenesis and metastasis. At present, the two factors are best measured using enzyme-linked immunosorbent assay (ELISA) in fresh frozen tumour tissue and are associated with the prognosis in node-negative breast cancer [29]. A comprehensive analysis of 8377 patients showed the good reproducibility of this examination method and confirmed the close association of uPA/PAI-1 gleichbarkeit der Resultate zu erreichen, wurden aktuell von einer internationalen Arbeitsgruppe Empfehlungen festgelegt [24]. Berücksichtigt man, dass sowohl Ki-67 als auch ER oder HER2-Testergebnisse inkorrekt sein können, haben vermehrte Qualitätskontrollen und Qualitätssicherungsprogramme eine große Bedeutung, um das prognostische und prädiktive Potenzial dieser Marker voll auszuschöpfen.

\section{Entwicklung von Biomarkern beim Mammakarzinom $\nabla$}

Zusätzlich zu den oben erwähnten etablierten klinisch-pathologischen Faktoren wurden zahlreiche moderne tumorbiologisch orientierte prognostische und prädiktive Faktoren in den letzten Dekaden untersucht. Von diesen werden allerdings nur der Hormonrezeptorstatus und HER2 mit einem hohen Evidenzlevel breit akzeptiert und in der klinischen Praxis eingesetzt. Um die Qualität der Forschung über Biomarker zu verbessern, wurde die Empfehlung REMARK (Reporting Recommendations of Tumor Marker Prognostic Studies)Kriterien eingeführt. REMARK beschreibt, welche Informationen, wie zum Beispiel Studiendesign, primäre Hyothese, Patienten- und Gewebecharakteristika, Nachweismethoden und statistische Analysemethoden, bei der Publikation einer Biomarkerstudie offen gelegt werden sollten [25]. Abhängig von der Qualität einer Biomarkerstudie können unterschiedliche Evidenzlevel für die einzelnen Marker vergeben werden [26]. Um das höchste Evidenzlevel zu erreichen, musste ein Biomarker prospektiv im Rahmen einer prospektiv randomisierten Studie untersucht werden. Mittlerweile wurde eine Modifikation dieser Evidenzlevel für Biomarker eingeführt, die bereits vorliegendes und archiviertes Gewebe stärker berücksichtigt [27]. Weiterhin wurde eine A-priori-Untersuchung in einer prospektiven randomisierten Studie als Goldstandard angesehen. Unter Berücksichtigung der Tatsache, dass solche Studien zur Tumormarkerevaluation allerdings organisatorisch und finanziell sehr aufwendig sind, wurden effizientere „prospektiv-retrospektive“ Ansätze unter Verwendung von archiviertem Material aus prospektiven Studien beschrieben. Ein solcher Ansatz kann ebenfalls Level-I-Evidenz erreichen, wenn die Resultate im Archivmaterial einer zweiten vergleichbaren Studie validiert werden [27].

Die Empfehlungen zur Verwendung von neueren Biomarkern beim Mammakarzinom wurden von der American Society of Clinical Oncology (ASCO) aktualisiert [28]. Zusätzlich zu ER und HER2 wurden noch Biomarker wie Urokinase-Plasminogen-Aktivator (uPA)/Plasminogen-Aktivator-Inhibitor-1 (PAI-1) und bestimmte Genexpressionsalgorithmen für den praktischen Einsatz empfohlen.

\section{Urokinase-Plasminogen-Aktivator| Plasminogen-Aktivator-Inhibitor-1} $\nabla$

uPA und PAI-1 sind Bestandteile des plasminogenaktivierenden Systems, die experimentell mit Invasion, Angiogenese und Metastasierung zusammen hängen. Diese beiden Faktoren können derzeit am besten mit Enzyme-Linked Immunosorbent Assay (ELISA) an frischem/gefrorenen Tumorgewebe gemessen werden und sind mit der Prognose beim nodal-negativen Mammakarzinom assoziiert [29]. Eine umfassende Analyse von 8377 Patientinnen zeigte die gute Reproduzierbarkeit der Untersuchungsmethode und bestätigte die enge Assoziation von uPA/PAI-1 und Prognose beim Mammakarzinom [30]. Die höchste Evidenzstufe wurde für diese Biomarker dann in einer prospektiv randomisierten multizentrischen Studie erreicht, in der gezeigt werden konnte, dass uPA (PAI-1 adjuvant unbehandelte 
and prognosis in breast cancer patients [30]. The highest level of evidence for these biomarkers was reached in a prospective randomised multicentric study which showed that uPA/PAI-1 nodenegative patients without adjuvant therapy could be stratified into a low-risk and a high-risk group [31].

Originally, these biomarkers were measured in fresh material obtained during surgery of the breast carcinoma. Thomssen et al. carried out a pilot study to investigate whether uPA/PAI-1 could be determined in tissue obtained from core needle biopsy. Their study showed a significant correlation between the values obtained from the biopsy and the material obtained at surgery [32].

\section{Multiparameter Gene Expression Analysis in Breast Cancer \\ $\nabla$}

\section{Intrinsic subtypes}

The ability to simultaneously measure the expression of many thousands of genes has amply demonstrated the wide heterogeneity of breast cancer [33]. Using hierarchical cluster analysis Perou et al. identified subtypes with similar gene expression, which they referred to as luminal, basal-like, erbB2-like and normallike. These so-called intrinsic subtypes differ in their associated prognosis [34], their patterns of metastasis [35], and their response to neoadjuvant chemotherapy [36]. As these first microarray analyses require fresh frozen tumour tissue which is not always available in practice, the original intrinsic gene list was reduced to 50 genes which can be detected in paraffinised tissue using quantitative real-time polymerase chain reaction (qRTPCR) [37]. The prognostic validity of the known subtypes could even be improved in this study by additionally including clinical information [37]. Triple negative is used as the immunohistochemical correlate for basal-like and HER2 positive is used for erbB2-like.

The limited reproducibility constitutes a problem when determining intrinsic subtypes. While basal-like and erbB2-like breast carcinomas could be reproduced in different datasets and by different investigators, achieving a reliable differentiation between luminal A and luminal B is much less certain $[38,39]$.

\section{Commercially Available Gene Expression Tests}

In Germany, 3 commercial gene expression tests are currently available and they have been recently rated by AGO as \pm .

\section{MammaPrint ${ }^{\circledR}$}

This test is based on investigations in which genes are identified which are variably expressed in breast cancer patients without adjuvant treatment over a period of 5 years, depending on their metastatic status [40]. The gene expression signatures of 70 genes obtained in this way were found to be superior to a clinico-pathological risk classification and have been validated in several studies [41,42]. To achieve the highest level of evidence this gene expression algorithm is being prospectively investigated in the Microarray In Node-negative Disease may Avoid ChemoTherapy (MINDACT) study [43]. One disadvantage in clinical practice is that the method requires fresh frozen tumour tissue. nodal-negative Patientinnen in eine Niedrig- und eine Hochrisikogruppe stratifizieren können [31].

Ursprünglich waren diese Biomarker am Frischmaterial nach Operation des Mammakarzinoms gemessen worden. Um die eine Bestimmung von uPA/PAI-1 an Gewebe aus Stanzbiopsien zu überprüfen, führten Thomssen et al. eine Pilotstudie durch. In dieser Untersuchung konnte eine signifikante Korrelation der aus der Stanze gemessenen Werte mit denen aus Operationsmaterial gezeigt werden [32].

\section{Multiparameter-Genexpressionsanalysen beim Mammakarzinom \\ $\nabla$}

Intrinsische Subtypen

Die Möglichkeit, die Expression von vielen tausend Genen simultan zu messen, hat die ausgeprägte Heterogenität von Brustkrebs vor Augen geführt [33]. Perou et al. konnten mithilfe von hierarchischen Cluster-Analysen Subtypen mit jeweils ähnlicher Genexpression identifizieren, die sie als luminal, basal-like, erbB2-like und normallike bezeichneten. Diese sogenannten intrinsischen Subtypen unterscheiden sich in ihrer Prognose [34] dem Metastasierungsmuster [35] und dem Ansprechen auf neoadjuvante Chemotherapie [36]. Da diese ersten Microarray-Analysen frisch gefrorenes Tumorgewebe benötigten, das in praxi nicht immer vorhanden ist, wurde die ursprüngliche intrinsische Genliste auf 50 Gene reduziert, die mittels quantitativer Real-Time-Polymerasekettenreaktion (qRT-PCR) in Paraffingewebe nachgewiesen werden können [37]. Die prognostische Aussagekraft der bekannten Subtypen konnte in dieser Arbeit durch zusätzliche Berücksichtigung klinischer Informationen noch verbessert werden [37]. Als immunhistochemisches Korrelat für basal-like wird triplenegative und für erbB2-like HER2-positiv verwendet.

Eine Schwierigkeit bei der Bestimmung der intrinsischen Subtypen ist die eingeschränkte Reproduzierbarkeit. Während sich basal-like und erbB2-like Mammakarzinome gut zwischen unterschiedlichen Datensätzen und unterschiedlichen Untersuchern reproduzieren lassen, ist die Unterscheidung zwischen luminal A und luminal B deutlich unzuverlässiger $[38,39]$.

\section{Kommerziell erhältliche Genexpressionstests}

In Deutschland werden derzeit 3 kommerziell erhältliche Genexpressionstests angeboten, die von der AGO aktuell mit dem Empfehlungsgrad \pm eingestuft werden.

\section{MammaPrint ${ }^{\circledR}$}

Dieser Test basiert auf Untersuchungen, bei denen Gene identifiziert wurden, die bei adjuvant unbehandelten Patientinnen je nach Metastasierungsstatus innerhalb von 5 Jahren unterschiedlich exprimiert waren [40]. Die auf diesem Weg generierte Genexpressionssignatur von 70 Genen war klinisch-pathologischen Risikoklassifikationen überlegen und konnte mehrfach validiert werden [41,42]. Um das höchste Evidenzlevel zu erreichen, wird dieser Genexpressionsalgorithmus prospektiv im Rahmen der Microarray In Node-negative Disease may Avoid ChemoTherapy (MINDACT) Studie untersucht [43]. Ein Nachteil für die praktische Anwendbarkeit ist, dass obligat frisch gefrorenes Tumorgewebe verwendet werden muss. 


\section{Oncotype DX ${ }^{\circledR}$}

Oncotype $\mathrm{DX}^{\circledR}$ is a commercially available gene expression assay which can be used in paraffinised material. It measures the expression of 21 genes using qRT-PCR and calculates a risk score (recurrence score). This test was developed in ER-positive patients who had adjuvant therapy with tamoxifen [44]. The test allowed a low-risk group consisting of $51 \%$ of patients to be defined, whose risk after endocrine therapy of developing distant metastases was $6.8 \%$. Further analysis showed that these low-risk patients would have only a low additional benefit from adjuvant chemotherapy [45].

The independent prognostic significance of Oncotype DX ${ }^{\circledR}$ was also demonstrated in node-positive patients who underwent anthracycline-based chemotherapy [46]. Here too, only patients with a high recurrence score benefited significantly from additional adjuvant chemotherapy. According to Simon et al. [27], Oncotype DX has already achieved evidence level I, but it is being additionally evaluated in the prospective randomised study TAILORx (Trial Assigning Individualized Options for Treatment) [47]. For Oncotype DX the paraffinised tissue has to be sent to a central laboratory in the USA for investigation.

\section{EndoPredict ${ }^{\circledR}$}

More recently, the EndoPredict ${ }^{\circledR}$ test has shown that stable qRT-PCR testing of paraffinised material can also be done locally by different molecular pathology departments, allowing a correct classification of the material into high-risk and low-risk groups with a high sensitivity and a specificity of $100 \%$. In postmenopausal ER positive/HER2 negative patients treated with endocrine therapy alone, this gene expression test, combined with tumour size and nodal status, allows a low-risk group to be defined consisting of $63 \%$ of patients [48]. This low-risk group was found to have a 10 -year risk for distant metastasis of $4 \%$ so that the potential additional benefit from adjuvant chemotherapy in these low-risk patients is questionable. The EndoPredict ${ }^{\circledR}$ test has achieved the highest level of evidence [27].

\section{First and Second Generation Gene Expression Signatures}

It has been increasingly realised that most prognostic and predictive gene expression signatures are mainly based on the measurement of ER regulated and proliferation-associated genes [49]. The high degree of concordance between the different assays is therefore not surprising [50]. First generation signatures had a strong prognostic validity, particularly for ER positive breast cancer [51]. The second generation signatures permit a prognosis to be made for ER negative breast cancer; they are signatures which primarily investigate immune cell transcripts [51].

\section{Immune System}

Recent interest has increasingly focused on the importance of the immune system for prognosis in breast cancer patients. Immune cell-associated gene expression motifs were found to have a prognostic value for ER negative [52,53] and HER2 positive [54] breast cancer.

In a systematic gene expression analysis using microarray in node-negative patients not treated with adjuvant therapy, metagenes were investigated as surrogates for co-regulated genes in a

\section{Oncotype DX ${ }^{\circledR}$}

Ein am Paraffinmaterial durchgeführter, kommerziell erhältlicher Genexpressionsassay ist Oncotype DX ${ }^{\circledR}$. Hierbei wird mittels qRT-PCR die Expression von 21 Genen gemessen und ein Risikoscore (Recurrence Score) berechnet. Dieser Test wurde bei ER-positiven Patientinnen entwickelt, die mit Tamoxifen adjuvant behandelt wurden [44]. Mit dem Test konnte eine 51\% der Patientinnen umfassende Niedrigrisikogruppe definiert werden, die unter endokriner Therapie alleine ein Risiko für das Auftreten von Fernmetastasen von 6,8\% hat. In einer weiteren Analyse wurde gezeigt, dass Patientinnen mit niedrigem Risiko nur einen geringen zusätzlichen Nutzen durch eine adjuvante Chemotherapie haben [45].

Diese unabhängige prognostische Bedeutung von Oncotype DX ${ }^{\circledR}$ konnte auch bei nodal-positiven Patientinnen, die mit einer anthrazyklinhaltigen Chemotherapie behandelt worden waren, gezeigt werden [46]. Auch hier profitierten lediglich die Patientinnen mit einem hohen Recurrence Score signifikant von einer zusätzlichen adjuvanten Chemotherapie. Oncotype DX hat nach Simon et al. [27] bereits Level-I-Evidenz erreicht, wird aber noch zusätzlich im Rahmen der prospektiv randomisierten Studie TAILORx (Trial Assigning Individualized Options for Treatment) evaluiert [47]. Für Oncotype DX muss das Paraffingewebe zur Durchführung der Untersuchung obligat in ein Zentrallabor in den USA verschickt werden.

\section{EndoPredict ${ }^{\circledR}$}

Dass ein stabiler qRT-PCR-Test an Paraffinmaterial allerdings auch dezentral in verschiedenen Molekularpathologien vor Ort durchgeführt werden kann und die korrekte Einstufung der Präparate in die Hochbzw. Niedrigrisikogruppe mit einer hohen Sensitivität und Spezifität von $100 \%$ ermöglicht, konnte aktuell für den EndoPredict ${ }^{\circledR}$ Test gezeigt werden. Dieser Genexpressionstest ermöglicht in Kombination mit Tumorgröße und Nodalstatus bei postmenopausalen ER-positiven/HER2-negativen Patientinnen, die ausschließlich mit einer endokrinen Therapie behandelt wurden, die Charakterisierung einer Niedrigrisikogruppe, die 63\% der Patientinnen umfasst [48]. Diese Niedrigrisikogruppe weist ein 10-Jahres-Fernmetastasenrisiko von $4 \%$ auf, sodass der mögliche zusätzliche Nutzen durch eine adjuvante Chemotherapie bei den Niedrigrisikopatientinnen kritisch hinterfragt werden kann. Der EndoPredict ${ }^{\circledR}$ Test hat das höchste Evidenzniveau [27].

\section{Genexpressionssignaturen \\ der 1. und 2. Generation \\ $\nabla$}

Mittlerweile wird zunehmend realisiert, dass die meisten prognostischen und prädiktiven Genexpressionssignaturen vor allem auf der Messung von ER-regulierten und proliferationsassoziierten Genen beruhen [49]. Daher ist es nicht überraschend, dass zwischen unterschiedlichen Assays eine hohe Konkordanz besteht [50]. Die Signaturen der 1. Generation weisen eine starke prognostische Aussagekraft vor allem bei ER-positiven Mammakarzinomen auf [51]. Bei den Signaturen der 2. Generation, die eine prognostische Aussage auch bei ER-negativen Mammakarzinomen erlauben, handelt es sich v.a. um Signaturen, die Immunzelltranskripte berücksichtigen [51].

\section{Immunsystem}

Die Bedeutung des Immunsystems für die Prognose des Mammakarzinoms rückt immer mehr in den Fokus des Interesses. Immunzellassoziierte Genexpressionsmotive zeigen prognostische Aussagekraft 


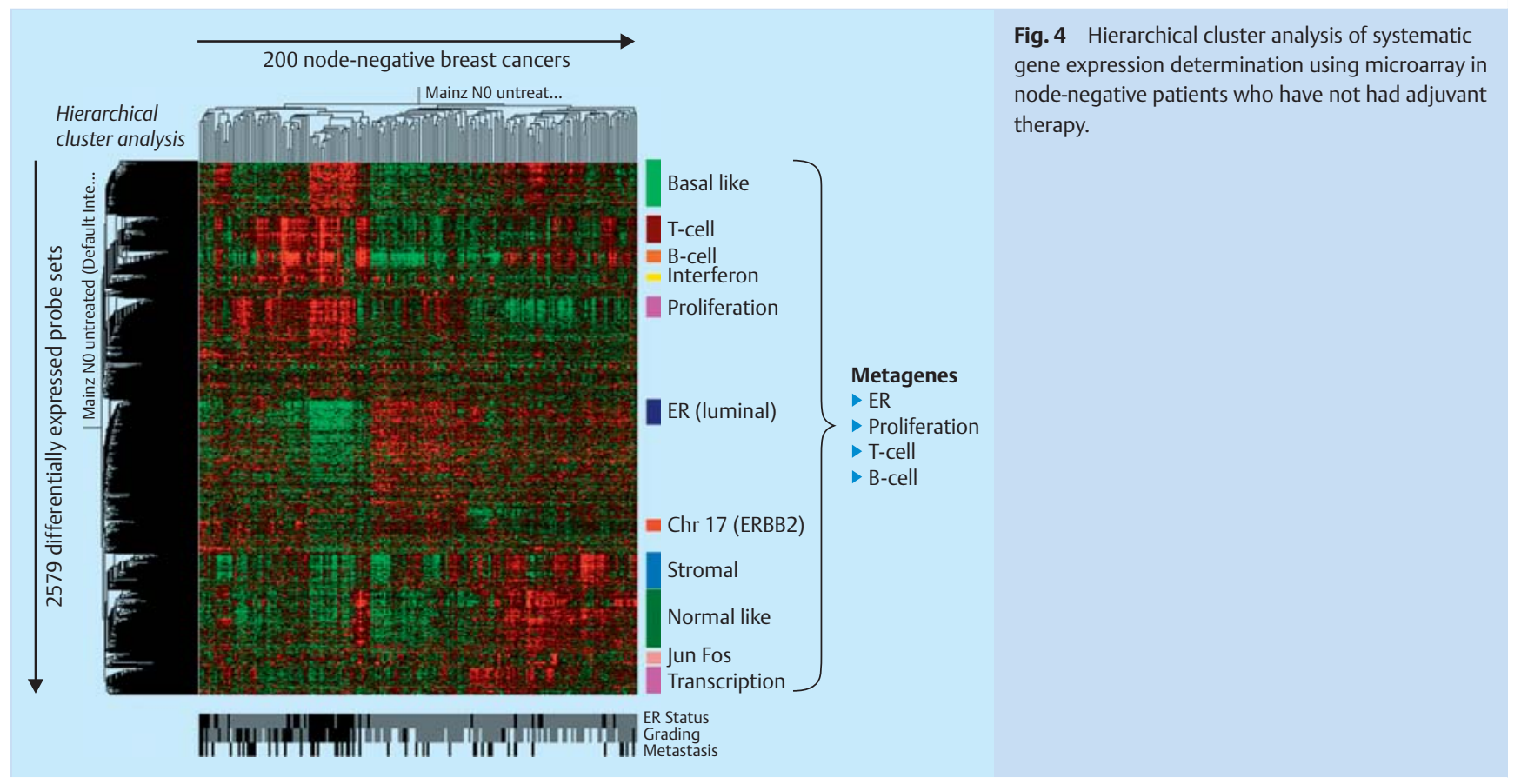

gene expression cluster ( Fig. 4). The study demonstrated the strong prognostic impact of ER-regulated and proliferation-associated genes [55]. In addition, B-cell and to a lesser extent T-cell metagenes were found to have a significant and independent prognostic role in carcinomas with high proliferative activity, irrespective of ER or HER2 status [55].

Following this study, Schmidt et al. investigated whether the protective effect of the B-cell signature could also be demonstrated for an individual gene. Immunoglobulin kappa C (IGKC) was chosen for investigation [56]. Using multivariate analysis, IGKC was found to be independently associated with prognosis for nodenegative breast cancer, both in the total patient collective and in all investigated subgroups (ER+HER2-, ER-HER2-, HER2+). In addition, a significant predictive impact of IGKC was found for patient response to neoadjuvant anthracycline-based chemotherapy. Confocal fluorescence microscopy showed that IGKC was expressed by tumour-infiltrating plasma cells. The antibodies formed by the plasma cells showed isotype switching of the immunoglobulin heavy chain to $\operatorname{IgG}$, which appears to indicate a specific antibody reaction to protein antigens and underlines the importance of the natural immune reaction in breast cancer [56].

The use of relevant axes (proliferation, ER, immune system) as part of a prognostic coordinate system could lead to a better understanding of the biological processes which affect prognosis in node-negative breast cancer [57]. In addition to the use of gene expression signatures, future methods such as next generation sequencing will permit even more precise characterisation of genomic alterations in breast cancer [58]. A first study done in this context using a genome-wide approach was able to identify T-cell receptors as a key gene whose expression is regulated by gene copy variants in the genome [59]. bei ER-negativen [52,53] und HER2-positiven [54] Mammakarzinomen.

Bei einer systematischen Genexpressionsanalyse mittels Microarray bei nodal-negativen und adjuvant unbehandelten Patientinnen wurden Metagene als Surrogat für koregulierte Gene in einem Genexpressions-Cluster untersucht $(\bullet$ Abb. 4). Hier zeigte sich zum einen die starke prognostische Bedeutung von ER-regulierten und proliferationsassoziierten Genen [55]. Darüber hinaus hatten das B-Zellund zu einem geringeren Anteil auch das T-Zell-Metagen eine signifikante und unabhängige Bedeutung bei schnell proliferierenden Mammakarzinomen ungeachtet des ER- oder HER2-Status [55].

Darauf aufbauend wurde untersucht, ob sich der protektive Effekt dieser B-Zell-Signatur auch in einem einzelnen Gen nachvollziehen lässt. Dazu wurde Immunglobulin Kappa C (IGKC) ausgewählt [56]. IGKC war multivariat unabhängig mit der Prognose bei nodal-negativen Mammakarzinomen im Gesamtkollektiv und in allen untersuchten Subgruppen (ER+HER2-, ER-HER2-, HER2+) assoziiert. Zusätzlich zeigte sich ein signifikanter prädiktiver Einfluss von IGKC für das Ansprechen auf eine neoadjuvante anthrazyklinhaltige Chemotherapie. Mittels konfokaler Fluoreszenzmikroskopie konnte nachgewiesen werden, dass IGKC von tumorinfiltrierenden Plasmazellen exprimiert wird. Die von den Plasmazellen gebildeten Antikörper zeigen einen Isotypenwechsel der Immunglobulin-Schwerketten zu IgG, was für eine spezifische Antikörperreaktion gegen Proteinantigene spricht und den Einfluss einer natürlich vorkommenden Immunreaktion beim Mammakarzinom unterstreicht [56].

Die Berücksichtigung dieser relevanten Achsen (Proliferation, ER, Immunsystem) im prognostischen Koordinatensystem kann zu einem besseren Verständnis der biologischen Prozesse führen, die für die Prognose beim nodal-negativen Mammakarzinom entscheidend sind [57]. In der Zukunft werden über Genexpressionssignaturen hinaus Verfahren wie Next Generation Sequencing eine noch genauere Charakterisierung der genomischen Alterationen bei Mammakarzinomen erlauben [58]. Eine erste Arbeit in diesem Zusammenhang konnte $z$. B. auch bei einem genomweiten Forschungsansatz den T-Zell-Rezeptor als ein Schlüsselgen identifizieren, welches durch Genkopienvarianten im gesamten Genom in Bezug auf die Genexpression reguliert wird [59]. 


\section{Predictive Biomarkers}

$\nabla$

\section{Oestrogen receptor as a predictive marker}

ER and HER2 are the best known examples of tumour biological markers which do not merely have a prognostic but also a predictive importance. ER is an extremely important tumour biological factor in breast cancer. Statistical analysis of the expression of thousands of genes in breast cancer patients using hierarchical cluster methods has demonstrated a basic division of breast cancers into different so-called intrinsic subtypes: mostly ER-positive luminal breast cancers and predominantly ER-negative intrinsic subgroups (erbB2-like, basal-like) [60]. Statistical analysis of gene expression can also be done using principal component analysis. In a study of 200 breast cancer patients who did not have adjuvant therapy it was shown that the first principal component, which by definition has the largest variance in the dataset, was almost parallel to the axis showing ER expression [55]. This emphasises the key importance of ER in the tumour biology of breast cancer.

ER is of only moderate prognostic importance for untreated patients. However, ER is a strong predictive factor for endocrine therapy such as tamoxifen. Meta-analysis has shown that patients with ER-negative breast cancer experience no therapeutic benefit from tamoxifen, and that the rate of recurrence of patients treated with tamoxifen is linked to their ER status [61]. Moreover, various studies have shown that ER negative breast carcinomas show a good response to chemotherapy. Obviously this is most apparent in patients who have had neoadjuvant therapy [62].

\section{HER2 as a predictive marker}

HER2 was first described as a marker associated with a worse prognosis in breast cancer [63]. This association has been confirmed in numerous subsequent studies, both with regard to HER2 over-expression and HER2 amplification [64].

Several retrospective studies have shown an association between HER2 and patient response to endocrine therapies [65], and sensitivity to anthracyclines [66] or taxanes [67]. These results could indicate a predictive effect of HER2 for these therapies but they are not undisputed and should at present not be used routinely in clinical practice. At the moment, the most important role for HER2 is as a predictive factor indicating patient response to HER2 targeted therapies such as trastuzumab [68].

HER2 is currently the most important example that a factor associated with a poor prognosis can serve as a target for a specific therapy. Thus, an apparently poor prognosis can become a comparatively favourable prognosis. This phenomenon has been reported both for patients with metastasis and for patients who have had adjuvant therapy [69].

\section{Ki-67 as a predictive marker}

Numerous study groups have also investigated the use of Ki-67 as a predictive factor in primary breast cancer. The predictive effect of Ki-67 is primarily associated with patient response to chemotherapy [70,71] and less with endocrine therapy [72]. Increased $\mathrm{Ki}-67$ expression in patients treated with letrozole in the Breast International Group (BIG) 1-98 study was associated with a better prognosis [73]. However this probably reflected the higher baseline risk of patients with increased Ki-67 levels. This example once again demonstrates the close connection between prognostic and predictive effect, particularly when factors are investigated in a collective which has received adjuvant medical treat-

\section{Prädiktive Biomarker}

$\boldsymbol{\nabla}$

\section{Der Östrogenrezeptor als Prädiktivmarker}

ER und HER2 sind die bekanntesten Beispiele für tumorbiologische Marker, die nicht nur eine prognostische, sondern auch eine prädiktive Bedeutung haben. ER ist ein tumorbiologisch eminent wichtiger Faktor beim Mammakarzinom. Wenn man die Expression von tausenden Genen in Mammakarzinomen mit hierarchischen Clustermethoden statistisch analysiert, zeigt sich die grundlegende Aufteilung der Mammakarzinome in unterschiedliche, sogenannte intrinsische Subtypen zwischen den zumeist ER-positiven luminalen Mammakarzinomen und den überwiegend ER-negativen intrinsischen Subgruppen (erbB2-like, basal-like) [60]. Als weitere statistische Analysemethode der Genexpression kann auch eine Hauptkomponentenanalyse vorgenommen werden. Hier konnte bei 200 adjuvant unbehandelten nodal-negativen Mammakarzinomen gezeigt werden, dass die Hauptkomponente 1, die definitionsgemäß die größte Varianz in einem Datensatz verkörpert, nahezu parallel zur Achse der ER-Expression verläuft [55]. Dies unterstreicht die zentrale Bedeutung von ER für die Tumorbiologie des Mammakarzinoms.

Die prognostische Bedeutung von ER ist in unbehandelten Patientinnen nur mäßig. ER ist allerdings ein starker prädiktiver Faktor für eine endokrine Therapie wie Tamoxifen. Metaanalysen zeigen, dass Patientinnen mit ER-negativen Mammakarzinomen keinen therapeutischen Nutzen von Tamoxifen haben, und die Rezidivrate tamoxifenbehandelter Patientinnen mit dem ER-Status zusammenhängt [61]. Verschiedene Arbeiten zeigen weiterhin, dass ER-negative Mammakarzinome gut auf Chemotherapie ansprechen. Dies zeigt sich naturgemäß am deutlichsten bei neoadjuvant behandelten $\mathrm{Pa}$ tientinnen [62].

\section{HER2 als Prädiktivmarker}

HER2 wurde initial als Marker beschrieben, der mit einer verschlechterten Prognose beim Mammakarzinom assoziiert ist [63]. Diese Assoziation konnte in zahlreichen Folgeuntersuchungen sowohl für die Überexpression als auch die Amplifikation von HER2 beschrieben werden [64].

Mehrere retrospektive Untersuchungen zeigen Zusammenhänge zwischen HER2 und dem Ansprechen auf endokrine Therapien [65], der Sensitivität für Anthrazykline [66] oder Taxane [67]. Diese Resultate können auf prädiktive Effekte von HER2 für diese Therapien hindeuten, sind allerdings nicht unwidersprochen und sollten derzeit nicht in der klinischen Routine berücksichtigt werden. Derzeit besteht die wichtigste Rolle von HER2 als prädiktiver Faktor für das Ansprechen auf eine HER2-gerichtete Therapie wie z.B. Trastuzumab [68].

HER2 ist derzeit das wichtigste Beispiel dafür, dass ein Faktor, der mit einer schlechteren Prognose assoziiert ist, als Ziel für eine spezifische Therapie dienen kann. Dadurch kann eine eigentlich schlechte Prognose zu einer vergleichsweise günstigen Prognose werden. Dieses Phänomen konnte bereits in der metastasierten [69] wie auch in der adjuvanten Situation gezeigt werden.

\section{Ki-67 als Prädiktivmarker}

Zahlreiche Arbeitsgruppen haben Ki-67 auch als prädiktiven Faktor beim primären Mammakarzinom untersucht. Der prädiktive Effekt von Ki-67 bezieht sich vor allem auf das Ansprechen auf eine Chemotherapie [70,71] und weniger auf eine endokrine Therapie [72]. Ein erhöhtes Ki-67 war bei Patientinnen, die im Rahmen der BIG-1-98-Studie behandelt wurden, mit einer verbesserten Prognose unter Letrozol assoziiert [73]. Dies allerdings reflektiert am ehesten ein höheres Ba- 
ment. AGO (German Gynaecological Oncology Group responsible for publishing guidelines) has assessed the predictive value of Ki67 as + (recommended).

\section{Topoisomerase Il $\alpha$ as a predictive marker}

As mentioned above, numerous studies have investigated the impact of HER2 on anthracycline sensitivity [66]. However, some authors have been unable to confirm an increased benefit of anthracyclines in HER2 positive breast cancer; paradoxically they even found that patients without HER2 amplification had a better survival if they received anthracycline-based adjuvant chemotherapy [74]. As topoisomerase II $\alpha$ (TOP2A) is a target structure for anthracyclines, it was postulated that the described association between HER2 and anthracycline sensitivity could actually be ascribed to the proximity of HER2 to the TOP2A gene locus on chromosome $17 q$. It was therefore obvious and comprehensible that amplification of TOP2A is predictive for anthracycline sensitivity [75]. Nevertheless, as with HER2, the predominantly retrospective studies on anthracycline sensitivity and TOP2A did not provide unequivocally consistent results. A prospectively planned biomarker investigation in a big adjuvant chemotherapy study was unable to substantiate an association with improved survival after anthracycline-based chemotherapy for either HER2 or TOP2A [76]. In this study, the most significant predictive factor was a duplication of chromosome 17 centromere enumeration probe (Ch17CEP). The authors concluded that this duplication could explain the observed inconsistent data on the impact of HER2 or TOP2A on anthracycline sensitivity [76].

The difficulty inherent in using HER2 and TOP2A as prognostic or predictive factors is increased even more by the relationship between gene amplification, RNA expression and protein expression. A pilot study of 53 primary breast cancers showed that HER2 amplification but not TOP2A amplification was closely associated with RNA and protein expression [77]. Based on these results, the prognostic validity of the RNA expression of both factors was investigated in 782 node-negative breast cancers and the predictive validity was investigated in a collective of $80 \mathrm{pa}-$ tients who underwent neoadjuvant anthracycline-based chemotherapy. In these studies, TOP2A was shown to be a significant prognostic factor and was also associated with a good response to anthracycline-based chemotherapy [77].

In addition to the prognostic importance of the biomarkers ER or HER2, they also have a predictive value as they serve as targets for endocrine or HER2-targeted therapies, and accordingly they have also been given the highest recommendation rating $(++)$ for predictive factors by AGO. Ki-67 is assessed as + (recommended) by AGO while use of topoisomerase II $\alpha$ as a predictive factor was only rated as \pm (conditionally recommended).

Overall, the biomarkers listed above have increasingly improved prediction and risk assessment, although stringent quality controls of these biomarkers are essential. It is crucial to ensure that the biomarkers described here are not used uncritically or inexpertly as this could lead to patients receiving insufficient treatment or the wrong treatment. sisrisiko der Patientinnen mit einem erhöhten Ki-67. Dieses Beispiel unterstreicht einmal mehr den engen Zusammenhang zwischen dem prognostischen und dem prädiktiven Effekt speziell, wenn solche Faktoren in einem Kollektiv untersucht werden, das adjuvant medikamentös behandelt wurde. Die AGO (deutsche Leitlinien-Kommission) bewertet Ki-67 als prädiktiven Faktor mit + (empfehlenswert).

\section{Topoisomerase Il $\alpha$ als Prädiktivmarker}

Wie oben erwähnt wurden bereits zahlreiche Untersuchungen zum Einfluss von HER2 auf die Anthrazyklinsensitivität durchgeführt [66]. Andere Arbeitsgruppen konnten hingegen einen gesteigerten Nutzen von Antrazyklinen bei HER2-positiven Mammakarzinomen nicht bestätigen und fanden paradoxerweise sogar, dass Patientinnen ohne HER2-Amplifikation ein verbessertes Überleben hatten, wenn sie mit einer anthrazyklinhaltigen adjuvanten Chemotherapie behandelt wurden [74]. Nachdem Topoisomerase II $\alpha$ (TOP2A) eine Zielstruktur für Anthrazykline ist, wurde postuliert, dass die beschriebene Assoziation zwischen HER2 und Anthrazyklinsensitivität tatsächlich auf die Nähe von HER2 zum TOP2A Genlocus auf Chromosom 17q zurückzuführen ist. Daher schien es klar und nachvollziehbar, dass eine Amplifikation von TOP2A prädiktiv für eine Anthrazyklinsensitivität ist [75]. Dennoch erbrachten die zumeist retrospektiv durchgeführten Untersuchungen zur Anthrazyklinsensitivität ähnlich wie bei HER2 auch für TOP2A kein zweifelsfrei konsistentes Bild. Eine prospektiv geplante Biomarkeruntersuchung in einer großen adjuvanten Chemotherapiestudie konnte weder für HER2 noch für TOP2A einen Zusammenhang mit einem verbesserten Überleben nach anthrazyklinhaltiger Chemotherapie nachweisen [76]. In dieser Studie war der aussagekräftigste prädiktive Faktor eine Duplikatur der Chromosom 17 Centromere Enumeration Probe (Ch17CEP). Die Autoren schlussfolgerten, dass diese Duplikatur die beobachtete inkonsistente Datenlage für den Einfluss von HER-2 oder TOP2A auf die Anthrazyklinsensitivität erklären könnte [76].

Die Komplexität der Interpretation von HER2 und TOP2A als prognostischer oder prädiktiver Faktor wird noch durch das Verhältnis von Genamplifikation, RNA-Expression und Proteinexpression gesteigert. In einer Pilotstudie an 53 primären Mammakarzinomen zeigte sich, dass zwar die HER2-Amplifikation, nicht aber die TOP2A-Amplifikation einen engen Zusammenhang mit RNA- und Proteinexpression aufweist [77]. Aufbauend auf diesen Ergebnissen wurden die prognostische Aussagekraft der RNA-Expression beider Faktoren bei 782 nodal-negativen Mammakarzinomen und die prädiktive Bedeutung in einem Kollektiv von 80 Patientinnen, die mit einer neoadjuvanten anthrazyklinhaltigen Chemotherapie behandelt worden waren, untersucht. TOP2A zeigte sich in diesen Untersuchungen als signifikanter prognostischer Faktor und war auch mit einem guten Ansprechen auf eine anthrazyklinhaltige Chemotherapie assoziiert [77].

Biomarker wie ER oder HER2 haben neben der prognostischen vor allem auch eine prädiktive Bedeutung, da sie als Ziel für eine endokrine oder HER-2-gerichtete Therapie dienen, und werden dementsprechend auch mit dem höchsten Empfehlungsgrad (++) für prädiktive Faktoren von der AGO (deutsche Leitlinien-Kommission) eingestuft. Ki-67 wird von der AGO mit + (empfehlenswert) und Topoisomerase Il $\alpha$ nur mit \pm (bedingt empfehlenswert) als prädiktiver Faktor bewertet. Insgesamt lassen die genannten Biomarker eine zunehmend verbesserte Prädiktion und Risikoabschätzung zu, wobei allerdings stringente Qualitätskontrollen für diese Biomarker essenziell sind. Es ist entscheidend, dass ein unkritischer oder unsachgemäßer Einsatz aufgeführten Biomarker nicht zu einer Unter- oder Fehltherapie der Patientinnen führen darf. 


\section{Conflict of Interest}

7

Dr. Marcus Schmidt: named inventor on patent applications regarding prediction of chemotherapeutic response in breast cancer and molecular markers for breast cancer prognosis. Received honoraria from Sividon and Genomic Health. Received previous funding from Siemens Healthcare Diagnostics Products GmbH.

\section{References}

1 Peto R, Boreham J, Clarke $M$ et al. UK and USA breast cancer deaths down 25\% in year 2000 at ages 20-69 years. Lancet 2000; 355: 1822 , DOI: $10.1016 / S 0140-6736(00) 02277-7$

2 Berry DA, Cronin KA, Plevritis SK et al. Effect of screening and adjuvant therapy on mortality from breast cancer. N Engl J Med 2005; 353: 1784-1792, DOI: 10.1056/NEJMoa050518

3 Fasching PA, Fehm T, Janni W et al. Breast cancer therapy - a state of the art review. Geburtsh Frauenheilk 2010; 70: 875-886, DOI: 10.1055/s0030-1250437

4 Kummel S, Kolberg HC, Luftner D et al. Breast cancer 2011 - new aspects. Geburtsh Frauenheilk 2011; 71: 939-953, DOI: 10.1055/s0031-1280313

5 Goldhirsch A, Coates AS, Gelber RD et al. First - select the target: better choice of adjuvant treatments for breast cancer patients. Ann Oncol 2006; 17: 1772-1776, DOI: 10.1093/annonc/mdl398

6 Liedtke C, Wolf MK, Kiesel L. New concepts for targeted systemic therapy in breast cancer. Geburtsh Frauenheilk 2010; 70: 625-633, DOI: $10.1055 / \mathrm{s}-0030-1250182$

7 Peto R, Davies C, Godwin J et al. Comparisons between different polychemotherapy regimens for early breast cancer: meta-analyses of long-term outcome among 100000 women in 123 randomised trials. Lancet 2012; 379: 432-444, DOI: 10.1016/S0140-6736(11)61625-5

8 Goldhirsch A, Wood WC, Coates AS et al. Strategies for subtypes - dealing with the diversity of breast cancer: highlights of the St. Gallen international expert consensus on the primary therapy of early breast cancer 2011. Ann Oncol 2011; 22: 1736-1747, DOI: 10.1093/annonc/ mdr304

9 Untch M, Gerber B, Mobus V et al. Zurich Consensus: statement of German experts on St. Gallen conference 2011 on breast cancer (Zurich 2011). Geburtsh Frauenheilk 2011; 71: 381-390, DOI: 10.1055/s0030-1271133

10 Ravdin PM, Siminoff LA, Davis GJ et al. Computer program to assist in making decisions about adjuvant therapy for women with early breast cancer. J Clin Oncol 2001; 19: 980-991

11 Olivotto IA, Bajdik CD, Ravdin PM et al. Population-based validation of the prognostic model ADJUVANT! for early breast cancer. J Clin Oncol 2005; 23: 2716-2725, DOI: 10.1200/JCO.2005.06.178

12 Mook S, Schmidt MK, Rutgers EJ et al. Calibration and discriminatory accuracy of prognosis calculation for breast cancer with the online Adjuvant! program: a hospital-based retrospective cohort study. Lancet Oncol 2009; 10: 1070-1076, DOI: 10.1016/S1470-2045(09)70254-2

13 Ozanne EM, Braithwaite D, Sepucha K et al. Sensitivity to input variability of the Adjuvant! online breast cancer prognostic model. J Clin Oncol 2009; 27: 214-219, DOI: 10.1200/JCO.2008.17.3914

14 Schmidt M, Victor A, Bratzel D et al. Long-term outcome prediction by clinicopathological risk classification algorithms in node-negative breast cancer - comparison between Adjuvant!, St Gallen, and a novel risk algorithm used in the prospective randomized Node-NegativeBreast Cancer-3 (NNBC-3) trial. Ann Oncol 2009; 20: 258-264

15 Wishart GC, Bajdik CD, Dicks E et al. PREDICT Plus: development and validation of a prognostic model for early breast cancer that includes HER2. Br J Cancer 2012; , DOI: 10.1038/bjc.2012.338

16 Wishart GC, Bajdik CD, Azzato EM et al. A population-based validation of the prognostic model PREDICT for early breast cancer. Eur J Surg Oncol 2011; 37: 411-417, DOI: 10.1016/j.ejso.2011.02.001

17 Wishart GC, Azzato EM, Greenberg DC et al. PREDICT: a new UK prognostic model that predicts survival following surgery for invasive breast cancer. Breast Cancer Res 2010; 12: R1, DOI: 10.1186/bcr2464
Interessenkonflikt

$\nabla$

Dr. Marcus Schmidt: namentlich genannter Erfinder auf Patentanmeldungen zur Vorhersage des Therapieansprechens beim Mammakarzinom und zum Einsatz von molekularen Markern als Prognosefaktoren bei Brustkrebs. Erhielt Honorarzahlungen von Sividon und Genomic Health. Erhielt früher Forschungsmittel von Siemens Healthcare Diagnostics Products GmbH.

18 Jung SY, Han W, Lee JW et al. Ki-67 expression gives additional prognostic information on St. Gallen 2007 and Adjuvant! online risk categories in early breast cancer. Ann Surg Oncol 2009; 16: 1112-1121, DOI: 10.1245/s10434-009-0334-7

19 Viale G, Regan MM, Mastropasqua MG et al. Predictive value of tumor Ki-67 expression in two randomized trials of adjuvant chemoendocrine therapy for node-negative breast cancer. J Natl Cancer Inst 2008; 100: 207-212, DOI: 10.1093/jnci/djm289

20 Urruticoechea A, Smith IE, Dowsett M. Proliferation marker Ki-67 in early breast cancer. J Clin Oncol 2005; 23: 7212-7220, DOI: 10.1200/ JCO.2005.07.501

21 Cheang MC, Chia SK, Voduc D et al. Ki67 index, HER2 status, and prognosis of patients with luminal B breast cancer. J Natl Cancer Inst 2009; 101: 736-750, DOI: 10.1093/jnci/djp082

22 Hammond ME, Hayes DF, Dowsett $M$ et al. American Society of Clinical Oncology/College of American Pathologists guideline recommendations for immunohistochemical testing of estrogen and progesterone receptors in breast cancer. J Clin Oncol 2010; 28: 2784-2795, DOI: 10.1200/JCO.2009.25.6529

23 Wolff AC, Hammond ME, Schwartz JN et al. American Society of Clinical Oncology/College of American Pathologists guideline recommendations for human epidermal growth factor receptor 2 testing in breast cancer. J Clin Oncol 2007; 25: 118-145, DOI: 10.1200/ JCO.2006.09.2775

24 Dowsett M, Nielsen TO, A'Hern R et al. Assessment of Ki67 in breast cancer: recommendations from the International Ki67 in Breast Cancer working group. J Natl Cancer Inst 2011; 103: 1656-1664, DOI: 10.1093/jnci/djr393

25 McShane LM, Altman DG, Sauerbrei W et al. Reporting recommendations for tumor marker prognostic studies. J Clin Oncol 2005; 23: 9067-9072, DOI: 10.1200/JCO.2004.01.0454

26 Hayes DF, Bast RC, Desch CE et al. Tumor marker utility grading system: a framework to evaluate clinical utility of tumor markers. J Natl Cancer Inst 1996; 88: 1456-1466

27 Simon RM, Paik S, Hayes DF. Use of archived specimens in evaluation of prognostic and predictive biomarkers. J Natl Cancer Inst 2009; 101: 1446-1452, DOI: 10.1093/jnci/djp335

28 Harris L, Fritsche H, Mennel R et al. American Society of Clinical Oncology 2007 update of recommendations for the use of tumor markers in breast cancer. J Clin Oncol 2007; 25: 5287-5312, DOI: 10.1200/ JCO.2007.14.2364

29 Janicke F, Schmitt M, Pache L et al. Urokinase (uPA) and its inhibitor PAI-1 are strong and independent prognostic factors in node-negative breast cancer. Breast Cancer Res Treat 1993; 24: 195-208

30 Look MP, van Putten WL, Duffy MJ et al. Pooled analysis of prognostic impact of urokinase-type plasminogen activator and its inhibitor PAI-1 in 8377 breast cancer patients. J Natl Cancer Inst 2002; 94: 116128

31 Janicke F, Prechtl A, Thomssen C et al. Randomized adjuvant chemotherapy trial in high-risk, lymph node-negative breast cancer patients identified by urokinase-type plasminogen activator and plasminogen activator inhibitor type 1. J Natl Cancer Inst 2001; 93: 913-920

32 Thomssen $C$, Harbeck $N$, Dittmer $J$ et al. Feasibility of measuring the prognostic factors UPA and PAI-1 in core needle biopsy breast cancer specimens. J Natl Cancer Inst 2009; 101: 1028-1029, DOI: 10.1093/ jnci/djp145 
33 Strehl JD, Wachter DL, Fasching PA et al. Invasive breast cancer: recognition of molecular subtypes. Breast Care (Basel) 2011; 6: 258-264, DOI: $10.1159 / 000331339$

34 Sorlie T, Perou CM, Tibshirani R et al. Gene expression patterns of breast carcinomas distinguish tumor subclasses with clinical implications. Proc Natl Acad Sci USA 2001; 98: 10869-10874, DOI: 10.1073/ pnas.191367098

35 Smid $M$, Wang $Y$, Zhang $Y$ et al. Subtypes of breast cancer show preferential site of relapse. Cancer Res 2008; 68: 3108-3114, DOI: 10.1158/ 0008-5472.CAN-07-5644

36 Rouzier R, Perou CM, Symmans WF et al. Breast cancer molecular subtypes respond differently to preoperative chemotherapy. Clin Cancer Res 2005; 11: 5678-5685, DOI: 10.1158/1078-0432.CCR-04-2421

37 Parker JS, Mullins M, Cheang MC et al. Supervised risk predictor of breast cancer based on intrinsic subtypes. J Clin Oncol 2009; 27: 1160-1167, DOI: 10.1200/JCO.2008.18.1370

38 Mackay A, Weigelt B, Grigoriadis A et al. Microarray-based class discovery for molecular classification of breast cancer: analysis of interobserver agreement. J Natl Cancer Inst 2011; 103: 662-673, DOI: 10.1093/jnci/djr071

39 Haibe-Kains B, Desmedt C, Loi S et al. A three-gene model to robustly identify breast cancer molecular subtypes. J Natl Cancer Inst 2012; 104: 311-325, DOI: $10.1093 /$ jnci/djr545

40 van't Veer LJ, Dai H, van de Vijver MJ et al. Gene expression profiling predicts clinical outcome of breast cancer. Nature 2002; 415: 530 536, DOI: $10.1038 / 415530$ a

41 van de Vijver MJ, He YD, van't Veer LJ et al. A gene-expression signature as a predictor of survival in breast cancer. N Engl J Med 2002; 347: 1999-2009, DOI: 10.1056/NEJMoa021967

42 Buyse M, Loi S, van't Veer L et al. Validation and clinical utility of a 70gene prognostic signature for women with node-negative breast cancer. J Natl Cancer Inst 2006; 98: 1183-1192, DOI: 10.1093/jnci/djj329

43 Cardoso F, van't Veer L, Rutgers E et al. Clinical application of the 70gene profile: the MINDACT trial. J Clin Oncol 2008; 26: 729-735, DOI: 10.1200/JCO.2007.14.3222

44 Paik S, Shak S, Tang G et al. A multigene assay to predict recurrence of tamoxifen-treated, node-negative breast cancer. N Engl J Med 2004; 351: 2817-2826, DOI: 10.1056/NEJMoa041588

45 Paik S, Tang G, Shak $S$ et al. Gene expression and benefit of chemotherapy in women with node-negative, estrogen receptor-positive breast cancer. J Clin Oncol 2006; 24: 3726-3734, DOI: 10.1200/ JCO.2005.04.7985

46 Albain KS, Barlow WE, Shak S et al. Prognostic and predictive value of the 21-gene recurrence score assay in postmenopausal women with node-positive, oestrogen-receptor-positive breast cancer on chemotherapy: a retrospective analysis of a randomised trial. Lancet Oncol 2010; 11: 55-65, DOI: 10.1016/S1470-2045(09)70314-6

47 Sparano JA, Paik S. Development of the 21-gene assay and its application in clinical practice and clinical trials. J Clin Oncol 2008; 26: 721728, DOI: $10.1200 / J C O .2007 .15 .1068$

48 Filipits M, Rudas M, Jakesz R et al. A new molecular predictor of distant recurrence in ER-positive, HER2-negative breast cancer adds independent information to conventional clinical risk factors. Clin Cancer Res 2011; 17: 6012-6020, DOI: 10.1158/1078-0432.CCR-11-0926

49 Sotiriou C, Pusztai L. Gene-expression signatures in breast cancer. N Engl J Med 2009; 360: 790-800, DOI: 10.1056/NEJMra0801289

50 Fan C, Oh DS, Wessels $L$ et al. Concordance among gene-expressionbased predictors for breast cancer. N Engl J Med 2006; 355: 560-569, DOI: 10.1056/NEJMoa052933

51 Reis-Filho JS, Pusztai L. Gene expression profiling in breast cancer: classification, prognostication, and prediction. Lancet 2011; 378: 18121823, DOI: 10.1016/S0140-6736(11)61539-0

52 Rody A, Holtrich U, Pusztai L et al. T-cell metagene predicts a favorable prognosis in estrogen receptor-negative and HER2-positive breast cancers. Breast Cancer Res 2009; 11: R15, DOI: 10.1186/bcr2234

53 Teschendorff AE, Miremadi A, Pinder SE et al. An immune response gene expression module identifies a good prognosis subtype in estrogen receptor negative breast cancer. Genome Biol 2007; 8: R157, DOI: 10.1186/gb-2007-8-8-r157

54 Alexe G, Dalgin GS, Scanfeld D et al. High expression of lymphocyte-associated genes in node-negative HER2+ breast cancers correlates with lower recurrence rates. Cancer Res 2007; 67: 10669-10676, DOI: 10.1158/0008-5472.CAN-07-0539
55 Schmidt M, Bohm D, von Torne C et al. The humoral immune system has a key prognostic impact in node-negative breast cancer. Cancer Res 2008; 68: 5405-5413, DOI: 10.1158/0008-5472.CAN-07-5206

56 Schmidt M, Hellwig B, Hammad S et al. A comprehensive analysis of human gene expression profiles identifies stromal immunoglobulin kappa $\mathrm{C}$ as a compatible prognostic marker in human solid tumors. Clin Cancer Res 2012; 18: 2695-2703, DOI: 10.1158/1078-0432.CCR$11-2210$

57 Schmidt M, Hengstler JG, von Torne C et al. Coordinates in the universe of node-negative breast cancer revisited. Cancer Res 2009; 69: 26952698, DOI: 10.1158/0008-5472.CAN-08-4013

58 Russnes HG, Navin N, Hicks J et al. Insight into the heterogeneity of breast cancer through next-generation sequencing. J Clin Invest 2011; 121: 3810-3818, DOI: 10.1172/JCI57088

59 Curtis C, Shah SP, Chin SF et al. The genomic and transcriptomic architecture of 2,000 breast tumours reveals novel subgroups. Nature 2012; 486: 346-352, DOI: 10.1038/nature10983

60 Perou CM, Sorlie T, Eisen MB et al. Molecular portraits of human breast tumours. Nature 2000; 406: 747-752, DOI: 10.1038/35021093

61 Early Breast Cancer Trialists' Collaborative Group. Effects of chemotherapy and hormonal therapy for early breast cancer on recurrence and 15-year survival: an overview of the randomised trials. Lancet 2005; 365: 1687-1717, DOI: 10.1016/S0140-6736(05)66544-0

62 Colleoni M, Viale G, Zahrieh D et al. Chemotherapy is more effective in patients with breast cancer not expressing steroid hormone receptors: a study of preoperative treatment. Clin Cancer Res 2004; 10: 66226628, DOI: 10.1158/1078-0432.CCR-04-0380

63 Slamon DJ, Clark GM, Wong SG et al. Human breast cancer: correlation of relapse and survival with amplification of the HER-2/neu oncogene. Science 1987; 235: 177-182

64 Ross JS, Slodkowska EA, Symmans WF et al. The HER-2 receptor and breast cancer: ten years of targeted anti-HER-2 therapy and personalized medicine. Oncologist 2009; 14: 320-368, DOI: 10.1634/ theoncologist.2008-0230

65 De Laurentiis M, Arpino G, Massarelli E et al. A meta-analysis on the interaction between HER-2 expression and response to endocrine treatment in advanced breast cancer. Clin Cancer Res 2005; 11: 4741-4748, DOI: 10.1158/1078-0432.CCR-04-2569

66 Pritchard KI, Shepherd LE, O'Malley FP et al. HER2 and responsiveness of breast cancer to adjuvant chemotherapy. N Engl J Med 2006; 354 2103-2111, DOI: 10.1056/NEJMoa054504

67 Hayes DF, Thor AD, Dressler LG et al. HER2 and response to paclitaxel in node-positive breast cancer. N Engl J Med 2007; 357: 1496-1506, DOI: 10.1056/NEJMoa071167

68 Slamon DJ, Leyland-Jones B, Shak S et al. Use of chemotherapy plus a monoclonal antibody against HER2 for metastatic breast cancer that overexpresses HER2. N Engl J Med 2001; 344: 783-792, DOI: 10.1056/ NEJM200103153441101

69 Dawood S, Broglio K, Buzdar AU et al. Prognosis of women with metastatic breast cancer by HER2 status and trastuzumab treatment: an institutional-based review. J Clin Oncol 2010; 28: 92-98, DOI: 10.1200/ JCO.2008.19.9844

70 Petit $T$, Wilt $M$, Velten $M$ et al. Comparative value of tumour grade, hormonal receptors, Ki-67, HER-2 and topoisomerase II alpha status as predictive markers in breast cancer patients treated with neoadjuvant anthracycline-based chemotherapy. Eur J Cancer 2004; 40: 205-211

71 Fasching PA, Heusinger K, Haeberle L et al. Ki67, chemotherapy response, and prognosis in breast cancer patients receiving neoadjuvant treatment. BMC cancer 2011; 11: 486, DOI: 10.1186/1471-2407-11486

72 Chang J, Powles TJ, Allred DC et al. Prediction of clinical outcome from primary tamoxifen by expression of biologic markers in breast cancer patients. Clin Cancer Res 2000; 6: 616-621

73 Viale G, Giobbie-Hurder A, Regan MM et al. Prognostic and predictive value of centrally reviewed Ki-67 labeling index in postmenopausal women with endocrine-responsive breast cancer: results from Breast International Group Trial 1-98 comparing adjuvant tamoxifen with letrozole. J Clin Oncol 2008; 26: 5569-5575, DOI: 10.1200/JCO.2008. 17.0829

74 Bartlett JM, Munro A, Cameron DA et al. Type 1 receptor tyrosine kinase profiles identify patients with enhanced benefit from anthracyclines in the BR9601 adjuvant breast cancer chemotherapy trial. J Clin Oncol 2008; 26: 5027-5035, DOI: 10.1200/JCO.2007.14.6597 
75 Knoop AS, Knudsen H, Balslev E et al. Retrospective analysis of topoisomerase IIa amplifications and deletions as predictive markers in primary breast cancer patients randomly assigned to cyclophosphamide, methotrexate, and fluorouracil or cyclophosphamide, epirubicin, and fluorouracil: Danish Breast Cancer Cooperative Group. J Clin Oncol 2005; 23: 7483-7490, DOI: 10.1200/JCO.2005.11.007

76 Bartlett JM, Munro AF, Dunn JA et al. Predictive markers of anthracycline benefit: a prospectively planned analysis of the UK National Epirubicin Adjuvant Trial (NEAT/BR9601). Lancet Oncol 2010; 11: 266-274, DOI: 10.1016/S1470-2045(10)70006-1
77 Brase JC, Schmidt M, Fischbach T et al. ERBB2 and TOP2A in breast cancer: a comprehensive analysis of gene amplification, RNA levels, and protein expression and their influence on prognosis and prediction. Clin Cancer Res 2010; 16: 2391-2401, DOI: 10.1158/1078-0432.CCR09-2471

Deutschsprachige Zusatzinformationen online abrufbar unter: www.thieme-connect.de/ejournals/toc/gebfra. 